University of Nebraska - Lincoln

DigitalCommons@University of Nebraska - Lincoln

Faculty Publications: Department of Teaching, Department of Teaching, Learning and Teacher Learning and Teacher Education

Education

Fall 2016

\title{
Black Female Adolescents and Racism in Schools: Experiences in a Colorblind Society
}

Nicole Joseph

Kara Viesca

Margarita Bianco

Follow this and additional works at: https://digitalcommons.unl.edu/teachlearnfacpub

Part of the Curriculum and Instruction Commons, and the Teacher Education and Professional

Development Commons

This Article is brought to you for free and open access by the Department of Teaching, Learning and Teacher Education at DigitalCommons@University of Nebraska - Lincoln. It has been accepted for inclusion in Faculty Publications: Department of Teaching, Learning and Teacher Education by an authorized administrator of DigitalCommons@University of Nebraska - Lincoln. 


\title{
Black $^{1}$ Female Adolescents and Racism in Schools: Experiences in a Colorblind Society
}

\author{
Nicole M. Joseph \\ Vanderbilt University \\ nicole.m.joseph@vanderbilt.edu \\ Kara Mitchell Viesca \\ University of Nebraska Lincoln \\ kara.viesca@unl.edu \\ Margarita Bianco \\ University of Colorado Denver \\ margarita.bianco@ucdenver.edu
}

\begin{abstract}
This article takes up the questions: (a) How do Black female adolescents define racism?, (b) What kind of experiences with racism to they report having in schools?, and (c) How can these perspectives and experiences inform educational reform efforts? The in-depth analysis of 18 student surveys and interviews revealed that most of the definitions of racism centered on prejudice, discrimination, and differential treatment; and most of the experiences the girls described regarding racism in school illustrated issues of prejudice, discrimination, and differential treatment as well as stereotypes, labels and low teacher expectations. Critical Race Theory, Critical Race Feminism, and Black Feminist Thought were used as interpretive theoretical frameworks. Implications for teacher education, secondary education and broad reform efforts are discussed.
\end{abstract}

Keywords: Black girls, racism, high school, colorblind ideology

In June, 2016, the United States Department of Education Office of Civil Rights released an initial analysis of the 2013-14 Civil Rights Data Collection (CRDC). The dataset includes data from $99.2 \%$ of all school districts in the U.S., $99.5 \%$ of all public schools, and over 50 million students. Initial analyses indicate that Black pre-school students are 3.6 times more likely than their White peers to be given one or more outof-school suspensions. In K-12 the trend continues with $18 \%$ of Black boys receiving suspensions and $10 \%$ of Black girls while only $6 \%$ of all K-12 students receive one or

\footnotetext{
1 Black refers to individuals who are multigenerationally born and raised in the US; a group of people whose families identified themselves as African American for generations, and for whom that identification is a crucial part of their sense of themselves, their families, and their communities. Black people have a distinct identity that has been shaped in large measure by a common history of slavery and by the political struggle of the Civil Rights Movement. Multigenerational African Americans have been enculturated in how the US socially constructs race and ethnicity (Clark, 2010).
} 
more out-of-school suspensions. Further, Black students are 1.9 times as likely to be expelled from school and are 2.3 times more likely to be disciplined through law enforcement than their White peers (U.S. DOE OCR, 2016). The extensive analysis of U.S. Civil Rights Data provides substantial evidence that there are issues of racial injustice in U.S. public schools. However, current policies and practices are overwhelmingly engaging in approaches that do not take a serious stance on issues of race, racism, or racial injustice. For instance, the Every Student Succeeds Act (ESSA) passed in December 2015 continues the approach from the previous federal law, No Child Left Behind (NCLB), of requiring disaggregated data based on race. Further, it requires actions be taken to limit school suspensions and curtail negative discipline policies (Brownstein, 2015) as well as to disaggregate data collected regarding school discipline policies by race (as well as by other "sub-groups" identified in the law). Although, those policies appear to be positive, The Civil Rights data above suggest that the groups most deeply impacted by these policies are Black students (boys and girls), yet the law takes no proactive stance regarding racial justice issues in its approach to changing discipline practices. By treating school discipline issues as "colorblind" (Bonilla-Silva, 2006), like ESSA does, current policies and approaches are not capable of overcoming serious issues of racial injustice in school and society. In fact, colorblind approaches serve to hide, minimalize and overlook serious issues of inequity based on race in school and society (Jackson, Sweeney, \& Welcher, 2014; López, 2007; Urrieta, 2006).

Black adolescent girls are an important group that is often overlooked in schools due to colorblind approaches and the complexities of multiple intersectional identities, based on race and gender. For Black girls, being overlooked can include issues of disempowerment whereby they are faced with hegemonic representations of beauty and femininity (Annamma, Anyon, Joseph, Farrar, Greer, Downing, \& Simmons, 2016; Muhammad, 2012), and are more likely than any other group of girls to be suspended and expelled from school (Annamma et al., 2016; Morris, 2012). Gender and racial stereotypes, in part, significantly contribute to the creation of such climates. Therefore, educational leaders and policy makers should pay close attention and engage in important work to improve the educational opportunities and outcomes for Black girls.

In order for educational opportunities and outcomes to improve for Black girls, explicit attention needs to be paid to race and its role in educational equity and inequity. However, prominent reforms from ESSA, teacher evaluation systems, charter schools, to teacher education reforms are essentially silent on issues of race, racism and racial justice and lack a proactive anti-racist stance. Bonilla-Silva (2006) describes what he calls "racism without racists" and suggests the ideology behind our national disposition is colorblind racism-or not seeing color. He argues that the racism of today is a dramatically different racism than that of the pre-Civil Rights era. By taking a different and implicit form, today's racism is easy to overlook, especially by those who are not negatively affected by it. Researchers have demonstrated how this colorblind ideology impacts issues of race and outcomes in schools, from perpetuating colorblindness through children's literature (Thomas, 2016; Winograd, 2011) to the dominance of a cultural narrative that race is not a significant issue in education (Mitchell, 2013; Pollock, 2005), to the perceptions of teachers (both pre- and in-service) and their attitudes towards students, families, and communities of color (Matias, 2013). The contemporarily dominant colorblind ideology is facing serious public scrutiny from the Black Lives Matter movement and their explicit platform for racial justice (The Movement for Black Lives, 2016). This ideology is further being challenged by the openly racist claims and actions of the Republican Presidential Candidate, 
Donald Trump, and his followers (Devega, 2016; O’Connor \& Marans, 2016). The current political and social climate, as illustrated through public discourse, does not suggest that the U.S. is actually a colorblind society, yet many still cling to colorblind ideals (e.g. \#AllLivesMatter).

Informed by this colorblind ideology, major education reform efforts are marching forward without any sincere attention to issues of racial justice. For example, the Gates Foundation recently funded the largest study of teacher effectiveness ever conducted in the U.S. They gathered 18,000 video observations of teaching practice across 6 districts with around 3,000 teachers and over 300 schools participating. None of the analyses or reports to date considered the role race or racism played in how effective teaching was conceptualized, defined, and/or measured nor how it might impact student learning outcomes (e.g., T. J. Kane \& Staiger, 2012). The results of this study are substantially impacting the development and implementation of teacher evaluation systems across the country. Other prominent teacher evaluation tools and studies have also been virtually silent on issues of racial justice (e.g. Danielson Framework, CLASS, etc.). In the context of a schooling system with such vast disparities for Black students, how can teacher quality be measured and defined without explicit attention to actions and approaches that proactively battle racial injustice? However, at this time, no proactive attention to race, racism, racialization, or race-based outcomes has been paid on a large scale. Effective teaching, like most current policies and approaches, is being defined from a colorblind stance that can only serve to replicate the status quo of racial injustice in U.S. public schools.

\section{Gender}

The complexities of gender in education and gendering are also important issues that get limited attention in education reform (Lopez, 2002). The consideration of gender and the role it plays in the experiences of students, especially students of color, is absent from the national policy discussions, despite reports focusing on subgroups like Black males and their dismal graduation rates (Holzman, 2012). Similarly, national efforts such as the National Assessment of Educational Progress (NAEP) present data disaggregated by gender but focus particularly on gaps in content areas such as science or mathematics. This kind of work acknowledges differences and disparities by gender, but discussions regarding gendered impacts on students' learning and outcomes are rare. For instance, the feminization of certain fields (such as teaching and nursing) and the extremely low numbers of women in masculinized fields (like science and engineering) are gendered outcomes requiring nuanced understandings of current processes of the distribution of power and privilege based on gender. Many of the STEM gender equity recommendations often center on providing more role models, and creating more real-life connections (McCrea, 2010). While those recommendations are noteworthy, other recommendations could include ongoing public discourse, in the form of symposia, conferences, or forums, which highlight and unpack the hostile, offensive, and unfavorable environments and interactions women in STEM experience simply because they are women (MacLachlan, 2006). Even with the 40th anniversary of Title IX, composite issues facing girls and women (especially of girls and women of color) are still invisible in national education reform discussions.

The perspectives and experiences of Black adolescent girls represent a collective voice from which the educational establishment can learn and better understand the complexities of race and gender issues in schools. Research on utilizing student voice in school reform and improvement has consistently shown the value of such practices (Cook-Sather, 2002; Fielding, 2001; R.G. Kane \& Maw, 2005; Wood, 2003). In fact, as Rudduck and Flutter (2000) argue, "to manage school improvement we 
need to look at schools from the pupils' perspective and that means tuning in to their experiences and views and creating a new order of experience for them as active participants" (p. 75). All students have a valuable perspective to offer for educational improvement. Considering the serious issues of gender and race oppression that are still so salient in education and society in the U.S. today (Collins, 2000; Omi \& Winant, 1994), this study seeks to contribute to conversations regarding needed reforms in the U.S. educational establishment by examining adolescent Black girls' perspectives on racism and its presence in schools. Our study seeks to answer the questions:

- How do Black female adolescents define racism?

- What kinds of experiences with racism do Black female adolescents report having in schools?

- How can these perspectives and experiences inform educational improvement efforts?

In the rest of this article we (1) review the literature on racism in schools and society, as well as Black girls, (2) describe Critical Race Theory and Feminism and Black Feminist Thought as our theoretical lens (3) discuss our methods for data collection and analysis, and (4) finally present our findings, interpretations, and implications for future research.

\section{Racism in Schools and Society}

As briefly described above, our system of public education is riddled with racial inequity. These inequities exist in school funding (Alemán, 2007; Holzman, Donnell, Fashola, Slama, Thapa, \& Beaudry, 2009; Wishon, 2004), in the distribution of qualified teachers (Darling-Hammond, 2011; Holzman, et al., 2009), and in access to challenging, college-preparatory curriculum (Holzman, et al., 2009; Lee, 2012), as well as in substantial racial and economic segregation (Fruchter, Hester, Mokhtar, \& Shahn, 2012; Logan, Oakley, \& Sowell, 2003; Orfield, Frankenberg, \& Garces, 2008; Orfield, Frankenberg, \& Lee, 2003). In our current system, outcomes for non-dominant groups in comparison to their White, middle-class counterparts are substantially differentiated. Berliner (2006) discussed international mathematics and literacy achievement data from the 2000 Program for International Student Assessment (PISA) and showed that the U.S. aggregate student population placed 19th among wealthy countries in mathematics and 14th in literacy and science. Yet when that data is further disaggregated by race, a very different picture emerges. Berliner (2006) found:

If the educational opportunities available to White students in our public schools were made available to all our students, the United States would have been the 7th highest scoring nation in mathematics, 2nd highest scoring nation in reading, and the 4th highest scoring nation in science. Schooling for millions of US White children is clearly working quite well. On the other hand, were our minority students 'nations,' they would score almost last among the industrialized countries of the world. (pp. 963-964)

Carnoy and Rothestein (2013) conducted a more recent analysis focused on socioeconomics that showed similar trends.

Using the 2009-2010 National Education Statistics data, Stillwell and Sable (2013) reported that, across the United States, the dropout rate for White students was $2.3 \%$ compared to $6.7 \%$ for American Indian/Alaska Native students, 5.5\% for Black students, and $5 \%$ for Latinx students. Similarly, the average freshman graduation rate (the on-time graduation rate) was substantially higher for White students (83\%) than for American Indian/Alaska Native students (69.1\%), Black students (66.1\%), and Latinx students(71.3\%). The Civil Rights data cited above illustrate inequity in discipline approaches that push heavier penalties onto students of color than White students. 
Such practices have been cited as part of the "school-to-prison pipeline" (M.C. James, 2011) where "schools are not a training ground for prisons, but are the key site at which technologies of control that govern Black oppression are deemed normal and necessary" (Sojoyner, 2013, 241). Essentially, what the Civil Rights data from the Department of Education suggest, as well as what the researchers above have asserted, is that "race matters" (Schuette v. BAMN, 2014) in the United States educational system.

Metzler (2010) describes the typical perspective of a White person in this contemporary racial moment: racism is a relic of the past; formal equality should be embraced; the United States has done a great deal for Blacks, but they never seem to think it is enough; one must walk on eggshells around Blacks for fear of stating something offensive; race is often used as an excuse by Blacks for their failure; and pretending that race does not matter makes race not matter. These perspectives play a powerful role in perpetuating racial inequity despite nearly eight-years of the country being led by a Black president, Barack Obama. Therefore, in our current era of colorblind racism we have a "new racial caste system" (Alexander, 2012) where "new tactics have been used for achieving the same goals" (p. 1), specifically white supremacy in an inequitable racial hierarchy. Over 50 years later, the institutional system of racist oppression named and labeled by Stokely Carmichael (1966) is still firmly in place.

In the context of schooling, institutional racism, white supremacy, and white privilege can turn into very real and tangible advantages. The disconnect that often exists between the white knowledge, skills, language and dispositions privileged in school contexts and those non-dominant populations encounter in their home environment is well documented (Fruchter, 2007; Heath, 1983; Schleppegrell, 2004) and is a major contributor to the persistent inequities plaguing our public schools. However, with a national disposition towards colorblind racism, the failure to address these issues is perpetuating racism and racist outcomes. The current colorblind culture of our schools, educational policies, and teacher education practices perpetuates the privileging of whiteness and fosters racist practices.

\section{Hot Mammas, Fatties, and other Controlling Images}

Operating from a colorblind stance can be damaging for Black female youth because they experience both racial and gender oppression and are often the victims of objectification (Collins, 2000). Young Black girls are objectified as "other" because of the unique history of slavery in the U.S. out of which emerged a master narrative that viewed Black women as property to be bought, non-human, and powerless (Collins, 2000). Black female youth are often viewed as "loud," "hot mammas," and "having an attitude" in school settings, which are views often derived from mainstream media that perpetuate those stereotypes. And yet the contextual influences and factors (i.e., institutional systems) are rarely examined and intersected into mainstream understandings of Black female adolescents (Koonce, 2012). Black adolescent girls are rarely positioned in a positive light; however, the challenges of being Black and female present issues that are nuanced and complicated. Black girls feel the effects of what Du Bois (1903) called "double consciousness;" they sense the need to navigate multiple identities as a result of not only wanting to express themselves to the world, but also to gain access to the culture of social power associated with the White or dominant society (Delpit, 1995). Mainstream research rarely considers these intersections and therefore research on young Black girls is often conducted through a deficit lens. Studies conducted through a deficit lens often focus only on high-risks behaviors and problems. 
For example, several studies over the last few years depict a deficit perspective of Black girls by emphasizing issues of sexual behavior and pregnancy (Lieberman, Berlin, Palen, \& Ashley, 2012; Wildsmith, Manlove, Jekielek, Moore, \& Mincielli, 2012); alcohol and drug use (Gray \& Montgomery, 2012; Tanner-Smith, Wilson, \& Lipsey, 2013), dating violence (Alleyne-Green, Colman-Cowger, Henry, 2012; Waller et al, 2012); excess weight and obesity (Leech \& Dias, 2012; Schneiderman, Mennen, Negriff \& Trickett, 2012); depression (Carter, Caldwell, Matusko, Antonucci, \& Jackson, 2011; Miller \& Taylor, 2012); and delinquency (Johnson, Giordano, Manning, \& Longmore, 2011; Khurana, Cooksey, \& Gavazzi, 2011). These studies also can fall prey to a type of essentialism, where characteristics like "sexual" are attributed not to the individuals making up the category, but to the category of "Black girls" itself (Phillips, 2010). An examination of current research on Black adolescent females suggests a need to utilize research perspectives and frameworks that are more affirming to Black girls. Research that focuses on the importance of Black adolescent females constructing meanings for themselves and resisting stereotypes and dominant discourses is needed.

\section{Theoretical Framework}

Critical Race Theory (CRT), Critical Race Feminism (CRF), and Black Feminist Thought (BFT) grounded our examination of the perspectives of Black adolescent females and racism in schools in a predominantly colorblind society. Critical Race Theory (CRT) has origins in Critical Legal Studies (CLS), but has made its way into the field of education (Ladson-Billings \& Tate, 1995). CLS began in the 1970s and represents the broad nomenclature in the legal field that analyzes, explains, and critiques accepted norms and standards in legal practice that claim to emphasize neutrality, objectivity, and truth. CLS was one of the first legal movements from the Civil Rights Era to challenge orthodox ideas about the objectivity of law that had oppressed minorities and White women for centuries (Wing, 2003). Therefore, many people of color and White women were attracted to CLS. However, as well meaning and progressive as CLS was, some scholars felt that CLS too often excluded the perspectives of people of color (men and women) and was thus not able to increase the scope of analyses beyond the worldview of White male elites (Tate, 1997). Thus began Critical Race Theory, particularly grounded in Derrick Bell's work (e.g., Bell, 1980).

Critical Race Theory has five tenets that position race as the object of analysis and discussions: challenge meritocracy, objectivity, neutrality, and ahistoricism; emphasize experiential knowledge (particularly of people of color); and support interdisciplinarity (Matsuda, Lawrence, Delgado, \& Crenshaw, 1993). According to Cornel West (1995), CRT is a "gasp of emancipatory hope that law can serve liberation rather than domination" (p. XII). The central goal of CRT is to study and transform the relationships between race, racism, and power by highlighting inherent racism in American society and promoting racial progress (Delgado \& Stefancic, 2001). However, some scholars felt that another level of granularity was needed in CRT: feminism.

Critical Race Feminism (CRF) is an important framework for studies examining the experiences of women of color in general. Although CRF points out that women of color have different experiences from men of color, and that these women are often devalued in American society, leaving women of color voiceless and invisible, CRF is limited in that it does not take into account the nuances of distinct experiences of Black women in the United States. Since this study is interrogating Black girls' definitions and experiences of racism in their high schools, we push further to use Black Feminist Thought (BFT). Before discussing BFT further, we acknowledge that both Critical Race Feminism and Black Feminist Thought critique the broader feminist notion that there is an essential female voice regardless of race or class, and that the 
essentialized feminist voice actually represents that of middle or upper-middle class White women. These frameworks foreground the lived experiences of women of color, which may not conform to the essentialist view of feminism or female experience. Finally, both frameworks utilize the concept of intersectionality that came from the work of Kimberlé Crenshaw (1991) and suggest that to understand the characteristic plight of women of color, one must look at the intersection of their race and gender identities. These multiple identities are salient for women of color and must be considered together in order to conduct holistic analyses of discrimination and other acts of oppression.

\section{Black Feminist Thought}

Black Feminist Thought advances Critical Race Theory and Critical Race Feminism by focusing particularly on the intellectual thought that emerges out of the nuanced examination and analysis of the distinct experiences that women of African descent have experienced in the U.S. The majority of African American women were brought to the U.S. to work as slaves and have remained in a position of oppression (Foster, Guy-Sheftall \& S. M. James, 2009; Hall, Scott \& Smith, 1982). Collins (2000) describes oppression as an "unjust situation where, systematically and over a long period of time, one group denies another group access to the resources of society" (p. 4). Thus she argues that race, class, and gender oppression associated with slavery have shaped all subsequent relationships that African American women have had within several different spheres, including their families and communities, employers, schools, the media, and among one another. Consequently, this unique collective historical experience created the political context for Black women's intellectual work and is a rationale for Black feminism.

BFT has six distinguishing characteristics that Collins (2000) suggests may not be unique and may align with other bodies of knowledge; however, it is the convergence of the features that gives Black Feminist Thought its unique contours. One characteristic of BFT is the acknowledgment that Black women's subordination within intersecting identities persists in the U.S. and Black Feminism is an activist and intellectual response to that oppressive system. As discussed in the literature, education research more often than not locates Black girls in subordinate positions related to who they are perceived to be as a collective; thus, there is a need to address this subordination in part by presenting characteristic analysis highlighting complex issues Black girls encounter because of intersecting identities of race and gender.

Collins (2000) describes the ways in which Black Feminism works to respond to oppression experienced by Black women and girls as a dialectical relationship because the two powers-domination from the oppressor and liberation by the oppressed-are in disagreement and represent different points of view about what represents the truth. Disagreement exists in part because the "profound substantive differences" (Chafe, 1977, p. 76) of Black women from other groups is not viewed as having value or legitimate in the eyes of scholars who conduct mainstream research (King, 1988), in part because Black epistemology or Black knowledge has always been contested in the U.S. Counter-narratives have always existed; however the dominant culture has always had control over whose knowledge represents science and truth (Harding, 1991). Black women have long recognized the oppression in their lives in the U.S., including the commonalities that are shared with all women. Black women have also realized that the collective oppressions that circumscribe their lives provide an important standpoint (Collins, 2000) for highlighting the uniqueness of Black women's subjugation. Black Feminist Thought consequently aims to empower Black women within the context of social injustices and, 
until the elimination of the intersecting oppressions, Black Feminism is necessary and needed.

A second feature of Black Feminism is the connection between experiences and ideas. Although all Black women face similar challenges that result from living in a society that historically devalues them, this commonality does not mean that individual women have had all of the same experiences, or that they all agree on the importance of the diverse experiences. As a result, it is important to understand that what Black women experience in their daily lives may or may not influence their consciousness about the broader collective.

Conceiving that U.S. Black women's collective historical experiences with oppression can stimulate a self-defined (individual) Black women's standpoint, which can in turn foster Black women's activism, is a third attribute of BFT. Self-defined standpoint feminism can stimulate resistance (Collins, 2000). Collins (2000) describes this notion as a dialogical relationship because the dialogue (internal, self-talk, misunderstandings, trust, distrust, etc.) between individual Black women and the collective is a communicative process that is to some degree mutually orienting. On the individual and group level, a dialogical relationship suggests that "changes in thinking may be accompanied by changed actions and that altered experiences may in turn stimulate a changed consciousness" (Collins, 2000, p. 30).

A fourth feature of BFT is the contributions of African American intellectuals. Black Feminism suggests that there are two levels of knowledge production for contribution; (1) the commonplace knowledge shared by African American women "growing from our everyday thoughts and actions" (Collins, 2000, p. 34), and (2) the expert specialized knowledge that emerges out of analysis of complex thought and theories by Black women like Anna J. Cooper. Since the first author is an African American scholar analyzing Black girls' experiences with racism in schools, she is contributing to the advancement of Black feminist standpoint and the broader field. Black women intellectuals are central to advancing BFT because their experiences provide critical insights into the conditions of oppression that those outside of the structures may not understand. Black women, both inside and outside of the academy, are less likely to abandon the struggles when the work seems overwhelming and the rewards are minimal. Additionally, Black women must continue to push the theme of self-definition because this develops empowerment; and Black intellectuals foster group accord, which promotes unambiguous coalitions with other groups.

A fifth distinguishing feature of BFT is that scholars who use this framework need to recognize that social conditions that confront African American women change and these changing conditions should stimulate new analysis of the common differences that make up U.S. Black womanhood. The final marker of BFT is that all analysis and discussion as it is applied to varying research should be committed to human solidarity and social justice.

Like Critical Race Theory, Critical Race Feminism and Black Feminist Thought have also made their way into the educational field. In fact, some scholars promote the use of CRF as a framework in examining issues impacting Black girls in schools (Evans-Winters \& Esposito, 2010). Theories, perspectives, and practices that emerge from CRT, CRF, and BFT are important to our study because we investigated how Black adolescent girls define racism in their respective schools, what type of experiences with racism in their schools they report, and how those perspectives and experiences might be used to inform educational reform and policy regarding improving their education. Evans-Winters and Esposito (2010) argue that there is a real need for 
more analysis by and for minority women that gives attention to the power of structural forces in schools and society, thus researching how Black adolescent girls experience a powerful structural force (racism) is important research. Accordingly, we used Critical Race Theory, Critical Race Feminism, and Black Feminist Thought as tools to analyze, interpret, and advance new understandings of racism, raise new questions, and point out ways racism can influence the lives of Black adolescent girls in schools.

\section{Methodology}

This qualitative study is part of a larger study examining the impacts and outcomes a program designed to help students of color from high poverty areas examine teaching as a career (see Bianco, Leech, \& Mitchell, 2011). Pathways2Teaching was launched during the 2010-2011 academic school year and began with a concurrent enrollment course at a local urban high school and a partnership between a School of Education and a local school district. In the first year, 33 students who participated in the program were all Black and/or Latinx. In the second year, the program expanded within the district to two schools and four sections of the class with over 70 students participating. The program continues to grow each year with more schools, teachers, and students becoming involved. However, the data analyzed in this study come from the first two years of the program.

\section{Data Sources}

As previously mentioned, the present study draws on a subset of data from a longitudinal study seeking to learn more about high school students of color considering a career in teaching. To answer our research questions, this study focuses on student surveys and interviews collected over two years (AY 2010-2011 and AY 2011-2012) to examine adolescent Black girls' experiences with racism in schools. The surveys were informal questionnaires containing mostly open-ended questions that were distributed in class and were used to conduct follow up interviews with students (lasting approximately 30 minutes) to probe their responses on the survey. The survey and subsequent interview contained questions regarding their experiences in school, their perceptions of racism, and their perceptions of the teaching profession. The participants in this study were recruited from two different high schools in one large urban district in the Southwestern U.S. - Ridge and Summit. Information regarding the participants is shown below in Table 1 (all names are pseudonyms). Two of the research participants (names in bold) are listed twice as they participated in the program during both years of data collection. Overall, we analyzed the perspectives of 18 Black adolescent girls regarding their definitions and experiences with racism in their high schools.

As mentioned above, the students in the Pathways2Teaching program come from two different schools. The program began at one school, Summit, and in the second year expanded to another, Ridge. Despite the same program focus on exploring teaching across both schools and even being taught by the same teacher in both schools, the two different schools represent very distinct schooling contexts.

Summit High School, a school serving predominantly Black and Latinx students, was one of the lowest performing schools in the district for many years and during the first year of this study the school board voted to close the school. The closing was initiated in year 2 of our study and no new students were admitted to Summit so only those students who were already there and chose to remain where part of Summit. Further, within the Summit building, other small schools were opened. These changes were extremely difficult for students at Summit and they often described feeling like they had a bad reputation as a poor school that they did not 
Table 1: Participant Information

\begin{tabular}{|l|c|c|c|c|c|}
\hline \multicolumn{1}{|c|}{ Name } & High School & $\begin{array}{c}\text { Year } \\
\text { in School }\end{array}$ & GPA & $\begin{array}{c}\text { First in family } \\
\text { to graduate } \\
\text { high school? }\end{array}$ & $\begin{array}{c}\text { First in family } \\
\text { to go to college? }\end{array}$ \\
\hline Adelae & Summit & Junior & 2.8 & No & No \\
\hline Evette & Summit & Senior & 2.9 & Yes & Yes \\
\hline Jaclynn & Summit & Senior & 4.0 & No & Yes \\
\hline Kalela & Summit & Senior & 3.7 & No & Don't Know \\
\hline Niambra & Summit & Junior & 3.0 & No & No \\
\hline Rhianna & Summit & Senior & 2.9 & No & No \\
\hline Liana & Summit & Junior & 2.1 & No & Don't Know \\
\hline Sarena & Summit & Senior & 3.0 & No & No \\
\hline Chanita & Summit & Senior & 2.7 & No & Yes \\
\hline Niambra & Summit & Senior & 3.5 & No & No \\
\hline Liana & Summit & Senior & 2.0 & No & No \\
\hline Taiquana & Summit & Junior & N/A & No & No \\
\hline Zandra & Summit & Senior & 3.3 & No & Yes \\
\hline Winslow & Summit & Senior & 3.6 & No & Yes \\
\hline Tallah & Summit & Senior & 3.0 & No & No \\
\hline Melicia & Ridge & Senior & 3.4 & No & No \\
\hline Ceyonne & Ridge & Senior & 2.6 & No & Yes \\
\hline Vantrice & Ridge & Senior & 2.8 & No & No \\
\hline Kishana & Ridge & Junior & 3.5 & No & No \\
\hline Delanna & Ridge & Junior & 4.7 & No & No \\
\hline
\end{tabular}

deserve. However, during our first year of the study, Summit had a graduation rate of less than $60 \%$.

Ridge High School, in contrast is a very diverse school with nearly a third of the population White, a third Black, and a third Latinx. However, Ridge has an International Baccalaureate (IB) ${ }^{2}$ program that substantially segregates the school. Most of the White students participate in the IB program and most of the students of color participate in what the Black girls in the present study term the "traditional" program. This within-school segregation has caused a great deal of division and controversy in the school and clearly informed the student's perceptions of racism. Yet, even students in the traditional program had access to challenging curricula and college preparation classes. The academic rigor at Ridge overall was substantially higher than that at Summit and therefore, the students at the two schools were granted disparate opportunities and reported extremely different schooling experiences.

Table 1 illustrates the participants with some general information regarding the school they attended, their GPA, and family background related to education.

\footnotetext{
${ }^{2}$ International Baccalaureate is a prestigious program offered at specific secondary institutions across the U.S. and the world. In addition to passing subject exams, IB student are required to take a Theory of Knowledge course, that requires 100 hours of instruction, the completion of an externally assessed essay of 1600 words (from a choice of six titles prescribed by the IB worth 67\%), and an internally assessed presentation (worth $33 \%$ ) on the candidate's chosen topic.
} 


\section{Data Analysis}

Our research team utilized Consensual Qualitative Research (Hill, Thompson, \& Williams, 1997; Hill, Knox, Thompson, Williams, Hess, \& Ladany, 2005) to both collectively and individually analyze the data and come to consensus on the codes, themes, domains and patterns. By engaging in individual and collective processes as well as continually checking the data to affirm our findings, our team came to consensus regarding the codes, themes, assertions, patterns and final results of our study. Line by line first level codes focused on three major themes: actions of differential treatment and discrimination; the assumptions surrounding prejudice, stereotypes, and labels; and low teacher expectations. After we discovered these overarching themes and agreed on our coding of the data according to these themes, we collaborated to determine the assertions and patterns conveyed in our data and found that there was a difference between how our participants defined racism and what they provided as examples of it in school. We also found that there were multiple levels of racism that our participants experienced in school: the institutional/systemic level, racism with teachers, and racism with students. Finally, we found that the Black adolescent females in our study engaged in acts of resistance to the racism they experienced at school. The following section offers a comprehensive discussion of the findings that emerged from this collective analysis.

\section{Findings}

The young women in this study had varied biographies that include concrete experiences, values, motivations and emotions that Critical Race Feminism and Black Feminist Thought suggest are critical for pushing the theme of self-definition. Furthermore, their narratives were not only distinct from those of White girls and men of color as both Critical Race Feminism points out; their stories were different even from other Black girls' stories as Black Feminism suggests. The Black adolescent girls in our study could be viewed as not having objective knowledge regarding issues of racism, but Code (1991) would suggest that all knowledge is subjective and tainted with human values and interests. Moreover, by using the analytical tools of CRT, Critical Race Feminism and Black Feminist Thought, we claim that the knowledge of the Black female adolescent participants is a space for analysis since their knowledge has been subjugated as part of the lineage of Black women's oppression in the U.S. and can provide important insights into experiences with racism.

Half of the participants (9/18) reported having experienced racism in schools. The girls at Ridge High School reported having experiences with racism at school at a higher rate (approximately 60\%) than the girls at Summit (approximately 50\%). Further, the students at Ridge had a great deal more detail in their stories of racism due to the heavily tracked and racially segregated nature of the school. Only two of the participants did not have a definition of racism to offer. Most of the definitions of racism centered on prejudice, discrimination, and differential treatment; most of the experiences the girls described regarding racism in school were about prejudice, discrimination, and differential treatment as well as stereotypes, labels and low teacher expectations. The following sections will describe in more detail the definitions of racism the girls provided, the experiences of racism they recounted, and the ways they resisted racism in school. All together, the participants in our study demonstrated that there are substantial issues of racism in schools for Black adolescent females that require attention and deliberate action to disrupt.

\section{“Treated Differently Than Another Race": Black Girls' Definitions of Racism}

In defining racism, the Black adolescent girls in our study focused mostly on discrimination and differential treatment. Their definitions acknowledged a racial hierarchy 
and, for some, emphasized issues regarding being judged or hated based on race. Tallah reported that racism is "prejudice against someone of a different race, or your same race, or any race." Tallah conceptualized racism as unfavorable opinions, feelings, and attitudes toward another group of people whose "race" is the same or different. Tallah's definition reflects aspects of what Collins (2000) calls the Matrix of Domination in that this model centers analysis from a both/and stance; a stance whereby all groups possess varying amounts of penalty and privilege in one historically created system. Consequently, depending on the context, an individual may be an oppressor, a member of an oppressed group, or simultaneously oppressor and oppressed. Black families are an example of a group that can simultaneously be oppressed and operate as an oppressor (Wilder \& Cain, 2011). Black girls learn about color consciousness not only from mainstream media, but also from their own families. Although the term colorism is not a part of everyday language, in a scholarly context it is defined as an "intraracial system of inequality based on skin color, hair texture, and facial features that bestows privilege and value on physical attributes that are closer to White" (Wilder \& Cain, 2011, p. 578). In their study of where, when, and how Black women learn about color consciousness, Wilder and Cain (2011) found that (1) colorism remains a social problem deeply affecting the lives of Black women, and (2) the influence of Black families in the introduction and maintenance of colorism may in part explain the survival of colorism within the Black community. Collins' (2006) analysis of feminism and racism contends that family rhetoric and practices play an important role in sending messages to Black girls and women that racial hierarchies are natural and normal.

Jaclynn described racism as "discrimination, and to go along with that, when people make you feel like you aren't good enough or you aren't equal, or don't include you in certain things because of what you look like." Vantrice stated that racism means "when you are treated differently, people react to you differently, or look at you differently just because of the color of your skin. Usually in a negative way." Evette commented that racism is when "one race hates another race," and Rhianna pointed out that racism is when someone is attacking a certain race. Each of the participant's definitions of racism illuminates both historical and contemporary understandings of Black oppression (prejudice and acts of discrimination) by Whites on the individual, institutional, and structural levels. From slavery to Jim Crow to Affirmative Action, and even to Ferguson, intentional attempts have been made to make Black individuals think that they are inferior, not equal to Whites, and that their lives and humanity do not matter. The institution of slavery gave rise to increasingly racist perspectives and feelings of inferiority among Blacks (Leary, 2005). During slavery Whites maintained racist ideologies and tried to demonstrate that Black people were uncivilized so that they could justify treating Blacks differently or inhumanely (Leary, 2005). This is why Critical Race Theory points out that there will always be a story about race in social, educational, economic, and political situations in relation to Black people. Additionally, as emphasized within Black Feminist Thought, Black women were brought to the U.S. primarily to work as slaves, but also to be White men's objects, and nannies to White children; thus racial and gendered oppression associated with slavery have impacted subsequent relationships in all other spheres for Blacks, including schools. This appears to be true for the participants in this study as well. Consequently, it appears that the adolescent Black girls in our study would benefit from more in-depth explorations of the evolution of racism to move beyond individual notions of racism and into the institutional and structural levels-concepts that help to explain exclusion from participation in the power decisions that shape all aspects of society, including schools (Carmichael, 1966). 
“Because I'm Black, Doesn't Mean I Can’t Learn”: Experiences with Racism in School

As mentioned above, our participants described instances of experiencing racism at school across multiple levels, from more systemic or institutional issues, to experiences with students and with teachers. By far, most instances of racism discussed by the Black girls focused on issues with teachers. However, the other experiences that occurred at the institutional or systemic level as well as with other students are also important and noteworthy. We organize this section into three sub-topics, including (1) In-School Program Segregation, (2) Institutional Discrimination, and (3) Racism Involving Teachers.

In-School Program Segregation. Several of our participants from Ridge High School discussed the issues around the internal segregation at Ridge, which can negatively influence teachers' academic expectations of students. One of our participants, Vantrice, discussed this segregation and its impact on students. She talked about how her experiences changed over time, from elementary through high school:

Well, let's think. In elementary school, middle school, high school...I really think it just gets different in high school...teachers are always going to have bias thoughts, well not all the time and not every single one, but teachers are often going to have bias thoughts on certain students because they think, "If you are from here..." Some teachers do it as a positive way, but some teachers think if you are from here, you are going to act like this, like you are rowdy or ghetto...this child is going to act like this and do this so they automatically treat that child wrong. In middle school it wasn't as much, but in high school it is worse because it's not as much the teachers, but the students. At our school, we are separated. And I don't know if it is as much self-segregation or we are separated because of the programs we are in, but you see that the kids in the IB are majority White and the kids in traditional are majority Black. And there are opportunities in IB that kids in traditional don't have. So like we are separated and we don't get that chance to spend time together and you live the rest of your life with whatever thoughts and views you have of the other people, you keep those ideas because that's all you know. (Vantrice's Interview, Ridge student)

Vantrice's perspective is interesting as she demonstrates how the institutional issues around racism have very clear and long-term impacts on students. She felt that racism was something she dealt more with from teachers before she got to high school and then she felt it was something she dealt more with in terms of students in high school. Vantrice's view also reflects what we know about the discourse of "othering," which emerges and develops when individuals or groups do not have opportunities to interact with and appreciate people who are different from themselves (Tatum, 1997).

Kishana started in the IB program at Ridge as a freshman, but felt that the teachers “didn't think I was going to be able to succeed and so it didn't seem like they were trying as hard or giving as much effort toward me learning the same things as the other people in my classes." She decided to leave the program, but has taken all Advanced Placement (AP) and honors classes, so she is still being rigorously prepared for college. When she was asked why she wanted to be in the IB program to begin with, she said, "because I was trying to challenge myself but I didn't want to overstay my welcome and didn't feel comfortable." Some of the challenges Kishana recounted in the IB program were focused on the low expectations of the teachers. But the institutional structure of her high school that substantially separates White students from students of color, also appeared to play a major role in her not feeling welcome in IB. Kishana's not feeling welcome in the prestigious IB program illuminates what Black Feminist thinkers call the structural domain of power. The structural 
domain of power encompasses how social institutions, such as schools, are organized to reproduce Black women's subordination over time (Collins, 2000). Collins (2000) points out how historically, in the U.S., the policies and practices of the legal system, labor markets, the housing industry, the news media, schools, and other social institution have worked "to disadvantage African American women" (p. 277). Kishana's choice to remove herself form the IB program because she did not feel welcomed and was not viewed as a capable student reveals footprints of how schools' nuanced policies and practices are designed to exclude Black girls from full citizenship (Collins, 2000).

Finally, Delanna, deliberately chose not to be in IB because "it was really full, filled up with White people." She further explained, "I like to be around everybody, not just one race." She also had heard about the significant amount of work required in IB courses and decided that AP and honors classes would challenge her enough, yet also leave her time for a high school social life. However, when Delanna talked about the IB program in the school she focused on the racism she viewed with students saying, "I feel like the IB students are racist towards the other students in traditional. I feel like they think they are more superior than us just because we aren't in those hard classes." Clearly, the institutional segregation at Ridge impacts how students view racism at the student level.

Institutional Discrimination. Vantrice also described an incident in which a White female student wrote an article in the school newspaper that was "basically a rant about how stupid other students looked when they did and wore certain things." However, the students that the White female targeted in her article were the Black girls in the school with some overtly racialized and derogatory language. Vantrice reported that many of the students were really angry and targeting the student writer. But, at some point, an adult endorsed the publishing of the piece in the school newspaper, an institutionally endorsed form of communication. From Vantrice's perspective this act of endorsement by the school demonstrated institutionalized discrimination against Black girls. Black Feminist thinkers or scholars help us understand this analysis because they argue that schools can be sites for reproducing controlling images of Black girls (Collins, 2000). Having a social institution privilege a White student's thinking about Black girls (in the newspaper) suggests that White students have power in this school and that Black girls are not valued in the same manner. This is a discourse that Vantrice as well as the other students could adopt and reify white privilege and oppression.

Our participants at Summit also discussed experiences with racism at the more institutional level as well as with other students. Adelae told the story of how she felt the school privileged Latinx students when it came to enforcing the dress code. She felt that her group of friends would get dress code violations for wearing the same thing as Latinx students and that they were unfairly targeted. Another student, Rhianna, discussed an issue she experienced at Summit with another student:

Rhianna: One day in class, in my fourth, err, my third period class, this guy was all like, 'hey Black girl,' and I felt like it was rude cause he knew my name but he just called me by my race instead.

Interviewer: He wasn't Black?

Rhianna: No.

Interviewer: This was a senior or when you were a senior?

Rhianna: Yeah, it was.

Interviewer: Did you say something to him?

Rhianna: Yeah, I said, "I have a name"

In this exchange we see how Rhianna felt an experience with sexism and racism at school came from another student, but also how she stood up for herself to resist that 
racism and sexism. Overall, participants had several examples of racism at the institutional level as well as with students. Yet, the greatest numbers of incidences reported by the participants were with teachers.

Racism involving Teachers. Taken as a whole, the experiences these Black female adolescents reported with racism in school involving teachers were grounded in differential treatment from teachers based on low expectations as well as stereotyping and prejudice. As mentioned above, Kishana felt that her teachers in the IB program did not think she would be able to succeed. She described that as "unfair." "Because I'm Black doesn't mean I can't learn.” She also recounted incidences outside the IB program where she felt teachers judged her before they knew her, but "once the class gets started and they get to know me they come around." She learned that proactively "not playing into the stereotype of I'm going to be ghetto and loud and disrespectful," helped the teachers come around and view her as a smart, capable student. Kishana, the daughter of a teacher, also felt that it was important to not disrespect teachers, as well as to not tolerate being disrespected by them. Her mom was actively engaged with issues at school and would work with Kishana to take on challenges she faced with teachers. Because several students had mentioned feeling stereotyped by teachers, we asked Kishana to tell us more about the stereotypes that are often reified by others. She said:

I feel like when I first walk into a classroom, the teacher expects, because of the way I dress and the people I talk to, they automatically expect that I'm going to be disrespectful, that I don't care about learning, that I'm only there, I'm being forced to be there, that I'm not going anywhere and that I'm only there because I would get in trouble for not being there. So, I feel like that is what they expect, so I try not to play into those stereotypes.

Interestingly, in our conversation about racism in school and the stereotypes associated with it, Kishana also called attention to other factors like ways of dressing, speaking, and which crowd a student hangs around with. Further, in our discussion around these issues of stereotypes that teachers give students, Kishana talked about how there are some people who will play into these stereotypes with teachers, "but there is a mass majority who don't."

Chanita discussed similar issues of prejudice and low expectations from teachers, but at a high school that was not part of this study. Before Chanita attended Summit high school, she attended a high school in a wealthy school district. She described not experiencing much racism at Summit where "the minority is the school. It's the majority of the population." But at her previous school she stated:

There were teachers who felt, or I feel like they felt less of me. And they, I was a smart student, so I think, I wouldn't say racism but I just don't think they thought I could live up to that. Like my ability, I just didn't think that they thought I was capable. (Chanita's Interview, Summit)

Here Chanita struggles to call the low expectations of her teachers racism, but confirms at another point in the interview that she had a strong sense that her teachers "had low expectations [of] me." She expressed surprise that at her previous school with a diverse student body saying, "you would think they wouldn't treat you different, but they, they did. But here, it's like we're all pretty much in a good, in a big group." The comparison between Chanita's perspectives and experiences around racism with the experiences from the students at Ridge suggests that students' 
perceptions of racism in school are deeply impacted by the composition of the student body where they attend school. It appears that the Black female adolescents in our study had stronger opinions about and more experiences to relate when they were in schools with diversity. The students at Summit, a predominantly Black and Latino/a school in a very high poverty area of the city, did not recognize the way their school was impacted by segregation before they walked through their school doors. It appears that Black girls would benefit from opportunities to learn more about education at the systemic level to gain perspective around the issues in their life that may be based on race that are not as obviously about race to adolescents unfamiliar with substantial issues in housing and education segregation in our country.

However, even at Summit, despite being a school with nearly all Black and Latinx students, many examples emerged of issues with racism in school, particularly with teachers. Tallah described a time when a White teacher told a Latinx student that he "looked guilty cuz he had on his hood." Tallah quickly drew a connection to the recent murder of Trayvon Martin and felt uncomfortable with the teacher saying that to a student. Niambra, a Summit student, described an incident that happened in $5^{\text {th }}$ grade before she came to Summit where her teacher told her sister that it was a shame Niambra was in her class because Niambra had recently immigrated from Africa and did not speak English well. Liana recounted an experience at Summit where a substitute teacher told the students that, "all minority students are nothing but good for being in jail and stealing." By the end of the day, everything the substitute had brought to school was stolen. Liana recalled, "it just really hurt us because like you don't even know us to judge us." Winslow also reported an incident where she felt accused by a teacher:

It was a while back. I think it was like my sophomore year and I was walking out of my math class. And the teacher was in there but I had to go back and get something and when I walked out of the classroom, the teacher started looking at my pocket like I had tooken [sic] something. And I just felt like I was discriminated against or something because, I think because of the color of my skin. Because, why would I steal something? Other girls walked out before us and they were Mexican. I don't know how to say that but they were Mexican yeah and he don't look at them, but he looked at my pocket.

All of these experiences with racism at school show how Black girls experience racism in both overt and less obvious ways. These statements also uncover a contextualized racial hierarchy that appears to be unique to each school setting. Further, it appears these experiences substantially impact the learning opportunities a Black female adolescent can have in a school with other students and teachers.

\section{"Being Yourself Causes the Biggest Controversy": Acts of Resistance}

The Black adolescent girls in our study talked about ways that they resisted personal and institutional acts of racism in their schools. Various acts of resistance included playing into or countering stereotypes and labels, standing up for themselves, and making deliberate choices regarding academic tracks. In describing her experiences with racism, Kishana discussed how her grandmother would always tell her that, "It is better to cause controversy than to be quiet. She said that being yourself causes the biggest controversy." Kishana's discussion of the importance of being oneself illustrates how being someone with great intellect and the ability to do well in school is a way to disrupt racism with teachers and inside of schools. This statement also suggests the power of self-definition and voice, an overarching theme of Black Feminist Thought. 
As described above, in one of Liana's freshman courses, a substitute told the class that all minorities were good for were two things-stealing and going to jail. Liana stated:

By the end of the day her purse, her wallet and everything just came up missing because what she said to us, we all took offense. Like you're accusing us of something we don't do... I guess so let me show you. It just really hurt us because like you don't even know us to judge us.

The expectation was that racial minorities would take things that do not belong to them, which suggest that their characters are wrought with dishonesty and they do not have any respect for others. As the literature points out, these stereotypes and controlling images can come from media, the internet, and other forms of communication that rarely positions racial minorities in a positive light and are historically rooted in racism (Collins, 2000).

Liana's recount of students stealing the substitute teacher's property is an example of her peers' resistance to racism by playing into stereotypes and labels. Liana believed that the students took the substitutes' wallet because they were "hurt" that the teacher had such low expectations of them as people. This particular act of resistance can be viewed as a part of a broader context of what Kelley (1993) calls "infrapolitics" (p. 77). During Jim Crow, oppressed groups challenged those in power by constructing a "dissident culture that manifested itself in daily conversations...jokes...or other cultural practices" (p. 77). Some of the forms of resistance came in the form of theft, destruction of property, or even open attacks on individuals or institutions (Kelley, 1993). Therefore, the students in this class were not being defiant, but participating in resisting the oppression they felt by the substitute teacher; which in the students mind, was a person who they viewed as having power to oppress.

Other acts of resistance occurred when issues of racism played out, and some of our participants stood up for themselves. As mentioned earlier, Rhianna reported that one day a White male student who was a senior said "hey Black girl!" Rhianna immediately turned around and stated "I have a name!" This account suggests that some Black girls have developing ideas of self-actualization, maximizing their potential to fulfill their own possibilities of being counted, visible, and important-a key aim of Black Feminist Thought. Although she could have remained silent, Rhianna chose to speak up, using spontaneity in her thoughts and actions. To make the world aware of her humanity and pride about who she was, she acted out emerging ideas of self-actualization, also the pinnacle of Maslow's Hierarchy of Needs (1943). Additionally, some Black feminists scholars have pointed out that Black women have always embodied an adversary stance to White male rule (Hull, Scott, \& Smith, 1982, p. 14).

Another form of resistance to issues of racism in school that the participants shared were in making their own choices about academic tracks of which they would be a part. As described above, both Delanna and Kishana deliberately chose to be in the "traditional" track at Ridge rather than the IB track as they felt the in-school segregation was negative to both their learning as well as their high school experience. Both were strong students, took mainly AP and honors classes, and were still on a college preparatory track, but felt that their presence in IB would not have served them well due to the racialized issues in the school.

\section{Discussion, Implications, and Future Research}

Although the participants in our study described their individual definitions of racism and discussed their individual experiences of racism in schools, our participants' perspectives provide evidence of how racism is institutionalized and 
continues to promote a racial hierarchy in schools and society today. Subsequently, their perspectives reveal the contradictions between a colorblind society and their lived experiences with race and racism in their high schools. Their gender and racial accounts suggest an important need for education reformers to pay close attention to their voices because disrupting Black girls' experiences with racism in schools can advance a more democratic schooling experience where they can feel valued and affirmed.

Our participants' collective perspectives and experiences with racism in schools can initially provide a self-defined standpoint on racism that, in turn, can foster Black female adolescent activism within schools. Their standpoint can inform educational reform and policy efforts in part through teacher education locally, regionally, and nationally. Teaching is a political endeavor; and while we know that we cannot rid society of politics, what we can do as educators is link teaching pedagogy to social change, so that all students, but especially Black girls might engage in the space of schooling as a site of possibility and positive resistance (Friere, 1973; Giroux, 2001; hooks, 1999). Engaging student voice in education reform is a different way of thinking based on convictions such as adolescents having unique perspectives on learning, teaching, and schooling; young people having insights that warrant not only the attention but also the responses of the adults who hold decision making power; and students being able to have afforded opportunities to actively shape their education (Cook-Sather, 2006). Clearly, the Black female participants in our study have had many kinds of experiences with racism in school. From these experiences, they also have ideas about how to improve school to battle these issues. What would it be like to be in a world where the major national reform agendas actually paid attention to these perspectives and these issues?

Kishana offered her perspective on how to solve the problem of racism in schools in the interaction below.

Kishana: The only way I can think of it is to wipe all the teachers out and have new ones. Because the teachers, especially here [Ridge], are so set in their ways in their mindsets of this is how it is going to work and if it doesn't they [meaning the students] are too stupid to learn. Because I know I've talked to several of my teachers and every time I've asked them to re-explain it they will explain it the same way. That doesn't make sense. If I'm saying I don't understand it, they should be able to explain it another way, to adapt and find a new way for me to learn. They need more workshops or something that teachers alternative ways of teaching, new methods or something.

Interviewer: Do you think it would help with some of these issues that you call institutionalized racism if we have more teachers of color?

Kishana: Uh-huh.

Interviewer: How so?

Kishana: Because I feel if we had teachers of color that actually cared about the system and want equality, we would have, we as students can't do much in having a say in things anymore. When we say something it isn't like, "hey that's cool," [but] it takes a backseat to what the teachers say. So it would put more priority to what is going on and more authority to what is being said.

According to Kishana, teachers need to think in different ways about how students might learn and think. She also felt they need to have more training on how to work with students to learn the material well. Additionally, she called for a massive reform movement to "wipe all the teachers out" in order to change their mindset and promote the idea that more teachers of color would be beneficial for students of 
color. Kishana's perspective is not unlike Counts' (1932) perspective when he pointed out to the progressive educators that teachers must be responsible in actively participating in reconstituting a democratic education. It appears that she is arguing for more teachers of color to be able to act as advocates for students as well as to support students in having a stronger voice in the system-a reform effort that could be viewed as more democratic.

If we have a system of teachers who look at Black girls as incapable, how can the system be equitable and the efforts at reform successful? Essentially, the assumptions and values that produce racist outcomes are the results of social, political, and institutional structures that continue to operate from the position of gender inequity and White normativity and therefore perpetuate White, male privilege (Collins, 2000). Utilizing the perspectives of Black female adolescents to understand the impacts and outcomes of these institutional practices is critical to disrupting the perpetuation of inequity at the intersection of race and gender for Black girls.

An alarming but not surprising finding of this study highlights that most instances of racism discussed by our participants focused on interactions, comments, and attitudes perpetuated by their White teachers. We view Kishana's call for increasing the diversity of the teacher workforce as critical and should not be ignored. How might Kishana and countless other Black young women's school experiences differ if they had more Black women teachers in school? We argue that Black girls need more Black female teachers throughout their pre-K to $\mathrm{PhD}$ educational trajectories. Beauboeuf-Lafontant (2002) describes the pedagogy of exemplary Black women teachers as "facets of womanism, an epistemological perspective based on the collective experiences of black women" (p. 71). Dixson (2003) suggests that many Black female teachers mentor and support their students by sharing the wisdom and knowledge that comes with their own experiences confronting racism and hostility and by "creating a curriculum that challenges the master narrative..." (p. 232). One implication from this study points to the need for deliberately creating opportunities to encourage young Black women to consider becoming teachers. Sadly, Gordon's (2000) research illustrates that Black teachers intentionally dissuade their Black students from entering the teacher workforce believing that there are better opportunities for their students to explore. Given the experiences with racism our students shared, we view this as a call to Black educators to reflect on their advice and help young Black women see teaching as an act of social justice-a way to engage in the disruption of racism experienced by other young women of color.

There is a need for further research to better understand Black girls and racism in schools in today's political era. Future inquires might include developing and using a valid and reliable survey instrument that measures Black girls perceptions of racism in schools. This would allow for a larger sample to analyze and help in thinking about generalizing across the population. Conducting additional interviews nationally to do comparative analysis geographically might also be a future study. Finally, an experimental study that uses an "understanding sexism and racism" intervention program with Black girls in high schools (along with a control group) could build upon what we already know about how issues of race, gender, and racism relate to to Black girls.

\section{References}

Alemán, E. J. (2007). Situating Texas school finance policy in a CRT framework: How "substantially equal” yields racial inequity. Educational Administration Quarterly, 43(5), 525-558.

Alexander, M. (2012). The new Jim Crow: Mass incarceration in the age of colorblindness. New York, NY: The New Press. 
Alleyne-Green, B., Coleman-Cowger, V. H., \& Henry, D. B. (2012). Dating violence perpetration and/or victimization and associated sexual risk behaviors among a sample of inner-city African American and Hispanic adolescent females. Journal of Interpersonal Violence, 27(8), 1457-1473.

Annamma, S. A., Anyon, Y., Joseph, N. M., Farrar, J., Greer, E., Downing, B., \& Simmons, J. (2016). Black girls and school discipline: the complexities of being overrepresented and understudied. Urban Education, 0042085916646610.

Beauboeuf-Lafontant, T. (2002). A womanist experience of caring: Understanding the pedagogy of exemplary black women teachers. The Urban Review, 34(1), 71-86.

Bell, D. (1980). Brown and the interest-convergence dilemma. In D. Bell (Ed.), Shades of Brown: New perspectives on school desegregation (pp. 90-106). New York: Teachers College Press.

Berliner, D. C. (2006). Our impoverished view of educational research. Teachers College Record, 108(6), 949-995. doi:10.1111/j.1467-9620.2006.00682.x.

Bianco, M., Leech, N. L., \& Mitchell, K. (2011). Pathways to teaching: African American male teens explore teaching as a career. The Journal of Negro Education, 368-383.

Bonilla-Silva, E. (2006). Racism without racists: Color-blind racism and the persistence of racial inequality in the united states (2nd ed.). Lanham, MD: Rowman \& Littlefield Publishers, Inc.

Brownstein, R. (2015). Education law a tool for ending school-to-prison pipeline. Retrieved from https:// www.splcenter.org/news/2015/12/14/education-law-tool-ending-school-prison-pipeline.

Carmichael, S. (1966). Toward Black liberation. The Massachusetts Review, 7(4), 639-651.

Carnoy, M. \& Rothstein, R. (2013). What do international tests really show about U.S. Student performance? Washington DC: Economic Policy Institute. Retrieved from http://www.epi.org/publication/us-studentperformance-testing/.

Carter, Caldwell, \& Matusko, Antonucci, \& Jackson (2011). Ethnicity, perceived pubertal timing, externalizing behaviors, and depressive symptoms among Black adolescent girls. Journal of Youth and Adolescence, 40(10), 1394-1406.

Chafe, W. H. (1977). Women and equality: Changing patterns in American culture. New York: Oxford University Press.

Code (1991). What can she know?: Feminist theory and the construction of knowledge. Ithaca: Cornell University Press.

Collins, P. H. (2000). Black feminist thought: Knowledge, consciousness, and the politics of empowerment (2nd ed.). New York, NY: Routledge.

Cook-Sather, A. (2002). Authorizing students' perspectives: Toward trust, dialogue, and change in education. Educational Researcher, 31(4), 3-14. doi:10.3102/0013189X03100400.

Cook-Sather, A. (2006). Sound, presence, and power: "Student voice” in educational research and reform. Curriculum Inquiry, 36(4), 359-390.

Crenshaw, K. (1991). Mapping the margins: Intersectionality, identity politics, and violence against women of color. Stanford law review, 1241-1299.

Darling-Hammond, L. (2011). Effective teaching as a civil right: How building instructional capacity can help the achievement gap. Voices in Urban Education, Fall, 44-58.

Delgado, R., \& Stefancic, J. (2001). Critical race theory: An introduction. New York, NY: New York University Press.

Delpit, L. (1995). Other people's children: Cultural conflict in the classroom. New York: NY: The New Press.

Devega, C. (2016, July 6). The disturbing data on republicans and racism: Trump backers are the most bigoted within the GOP. Salon. Retrieved from http://www.salon.com/2016/07/06/the_disturbing_data_ on_republicans_and_racism_trump_backers_are_the_most_bigoted_within_the_gop/.

Dixson, A. D. (2003). Let's do this!” Black women teachers' politics and pedagogy. Urban Education, 38(2), 217-23

Du Bois, W. E. B. (1903). The souls of Black folk. New York, NY: Dover.

Evans-Winters, V. E., \& Esposito, J. (2010). Other people's daughters: Critical race feminism and black girls' education. Educational Foundations, 11-24.

Fielding, M. (2001). Students as radical agents of change. Journal of Educational Change, 2(2), $123-141$. doi:10.1023/A:101794921344.

Fruchter, N. (2007). Urban schools public will: Making education work for all our children. New York, NY: Teachers College Press.

Fruchter, N., Hester, M., Mokhtar, C., \& Shahn, Z. (2012). Is demography still destiny? Neighborhood demographics and public high school students' readiness for college in New York City. Providence, RI: Annenberg Institute for School Reform. Retrieved from http://annenberginstitute.org/product/ IsDemographyStillDestiny.

Giroux, H. A. (2001). Theory and resistance in education: Towards a pedagogy for the opposition. Westport, Connecticut: Bergin and Garvey.

Gray, C. M., \& Montgomery, M. J. (2012). Links between alcohol and other drug problems and maltreatment among adolescent girls: Perceived discrimination, ethnic identity, and ethnic orientation as moderators. Child abuse \& neglect, 36(5), 449-460.

Harding, S. G. (1991). Whose science? Whose knowledge?: Thinking from women's lives. Cornell University Press.

Heath, S. B. (1983). Ways with words: Languages, life and work in communities and classrooms. New York, NY: Cambridge University Press. 
Hill, C. E., Knox, S., Thompson, B. J., Williams, E. N., Hess, S. A., \& Ladany, N. (2005). Consensual qualitative research: An update. Journal of Counseling Psychology, 52(2), 196-205.

Hill, C. E., Thompson, B. J., \& Williams, E. N. (1997). A guide to conducting consensual qualitative research. The Counseling Psychologist, 25(4), 517-572. doi:10.1177/001100009725400.

Holzman, M. (2012). The urgency of now: The Schott 50 state report on public education and Black males 2012. Cambridge MA: Schott Foundation for Public Education. Retrieved from http://blackboysreport.org/.

Holzman, M., Donnell, C. M., Fashola, O. S., Slama, R., Thapa, A., \& Beaudry, A. E. (2009). Lost opportunity: A 50 state report on the opportunity to learn in America. Cambridge MA: Schott Foundation for Public Education. Retrieved from http://www.otlstatereport.org/.

hooks, b. (1999). Talking back: Thinking feminist, thinking Black. Cambridge, MA: South End Press.

Hull, G. T., Scott, P. B., \& Smith, B. (Eds.). (1982). The women are White, all the Blacks are men, but some of us are Brave: Black women's studies. New York: The Feminist Press at CUNY.

Jackson, R., Sweeney, K., \& Welcher, A. (2014). It just happens: Colorblind ideology and undergraduate explanations of racial interaction on campus. Education, Citizenship and Social Justice, 9(3), 191-208. doi:10.1177/1746197914542553.

James, M. C. (2011). Toward systems of opportunity: How to cap pipelines to prisons in schools. Journal of Curriculum and Pedagogy, 8(2), 123-127. doi:10.1080/15505170.2011.624894.

James, S. M., Foster, F. S., \& Guy-Sheftall, B. (Eds.). (2009). Still brave: The evolution of Black women studies. Old Westbury, NY: The Feminist Press.

Johnson, W. L., Giordano, P. C., Manning, W. D., \& Longmore, M. A. (2011). Parent-child relations and offending during young adulthood. Journal of youth and adolescence, 40(7), 786-799.

Kane, R. G., \& Maw, N. (2005). Making sense of learning at secondary school: Involving students to improve teaching practice. Cambridge Journal of Education, 35(3), 311-322. doi:10.1080/0305764050031902.

Kane, T. J., \& Staiger, D. O. (2012). Gathering feedback for teaching: Combining high-quality observations with student surveys and achievement gains. Bill \& Melinda Gates Foundation. Retrieved from http:// www.metproject.org/downloads/MET_Gathering_Feedback_Research_Paper.pdf.

Kelley, R. D. G. (1993). "We are not what we seem:” Rethinking Black working class opposition in the Jim Crow south. The Journal of American History, 80(1), 75-112.

Khurana, A., Cooksey, E. C., \& Gavazzi, S. M. (2011). Juvenile delinquency and teenage Pregnancy: A comparison of ecological risk profiles among midwestern White and Black female juvenile offenders. Psychology of Women Quarterly, 35(2), 282-289.

King, D. K. (1988). Multiple jeopardy, multiple consciousness: The context of a Black feminist ideology. Signs, 14(1), 42-72.

Koonce, J. B. (2012). “Oh, those loud Black girls!”: A phenomenological study of Black girls talking with an attitude. Journal of Language and Literacy Education, 8(2), 26-46.

Ladson-Billings, G. \& Tate, W. F. (1995). Toward critical race theory of education. Teachers College Record, 97(1), 48-68.

Leary, J. D. (2005). Post traumatic slave syndrome: America's legacy of enduring injury and healing. Milwaukie, OR: Uptone Press.

Lee, J. (2012). College for all. Educational Researcher, 41(2), 43-55. doi:10.3102/0013189X11432746.

Leech, T. G., \& Dias, J. J. (2012). Risky sexual behavior: A race-specific social consequence of obesity. Journal of youth and adolescence, 41(1), 41-52.

Lieberman, L. D., Berlin, C., Palen, L. A., \& Ashley, O. S. (2012). A theater-based approach to primary prevention of sexual behavior for early adolescents. The Journal of Early Adolescence, 32(5), 730-753.

Logan, J. R., Oakley, D., \& Sowell, J. (2003). Segregation in neighborhoods and schools: Impacts on minority children in the Boston region. Harvard Color Lines Conference, Harvard University.

Lopez, N. (2002). Rewriting race and gender high school curriculum: Second generation Dominicans in New York city. Teachers College Record, 104(6), 1187-120.

López, I. F. H. (2007). A nation of minorities: Race, ethnicity, and reactionary colorblindness. Stanford Law Review, 59(4), 985-1063.

MacLachlan, A. J. (2006). The graduate experience of women in STEM and how it could be improved. In J. M. Bystydzienski \& S. R. Bird (Eds.), Removing barriers: Women in academic science, technology, engineering, and mathematics, (pp. 237-253). Bloomingtoin, IN: Indiana University Press.

Maslow, A. H. (1943). A theory of human motivation. Psychological Review, 50, 370-396.

Matias, C. E. (2013). On the 'flip' side: A teacher educator of color unveiling the dangerous minds of White teacher candidates. Teacher Education Quarterly, 40(2), 53.

Matsuda, M., Lawrence, C., Delgado, R., \& Crenshaw, K. W. (1993). Words that wound: Critical race theory, assaultive speech and the first amendment. Boulder, CO: Westview Press.

McCrea, B. (2010). Engaging girls in STEM. The Journal, retrieved March 9 at http://www.carlsbadusd. k12.ca.us/Pdfs/News/BoardBlast/Engaging_Girls_in_STEM1010.pdf.

Miller, B., \& Taylor, J. (2012). Racial and socioeconomic status differences in depressive symptoms among Black and White youth: An examination of the mediating effects of family structure, stress and support. Journal of youth and adolescence, 41(4), 426-437.

Mitchell, K. (2013). Race, difference, meritocracy, and English: Majoritarian stories in the education of secondary multilingual learners. Race Ethnicity and Education, 16(3), 339-364.

Morris, M. (2012). Race, gender, and the school-to-prison pipeline: Expanding our discussion to include Black girls. New York, NY: African American Policy Forum. Retrieved from http://aapf.org/wpcontent/ uploads/2012/08/Morris-Race-Gender-and-the-School-to-Prison-Pipeline.pdf. 
Muhammad, G. E. (2012). Creating spaces for Black adolescent girls to “write it out!” Journal of Adolescent and Adulty Literacy, 56(3), 203-211.

O’Connor, L., \& Marans, D. (2016, July 21). Here are 10 examples of donald trump being racist. The Huffington Post. Retrieved from http://www.huffingtonpost.com/entry/donald-trump-racist-examples us_56d47177e4b03260bf777e83.

Omi, M., \& Winant, H. (1994). Racial formation in the United States: From the 1960s to the 1990s (2nd ed.). New York, NY: Routledge.

Orfield, G., Frankenberg, E., \& Garces, L. M. (2008). Statement of American social scientists of research on school desegregation to the U.S. Supreme Court in "Parents v. Seattle School District" and "Meredith v. Jefferson County." Urban Review: Issues and Ideas in Public Education, 40(1), 96-136. doi: 10.1007/ s11256-007-0073-7.

Orfield, G., Frankenberg, E., \& Lee, C. (2003). The resurgence of school segregation. Educational Leadership, 60(4), 16-20.

Phillips, A. (2010). What's wrong with essentialism? Distinktion: Scandinavian Journal of Social Theory, 11(1), 47-60.

Pollock, M. (2005). Colormute: Race talk dilemmas in an American school. Princeton, NJ: Princeton University Press.

Rudduck, J., \& Flutter, J. (2000). Pupil participation and pupil perspective: 'Carving a new order of experience'. Cambridge Journal of Education, 30(1), 75-89. doi:10.1080/03057640050005780.

Schleppegrell, M. J. (2004). The language of school: A functional linguistics perspective. Mahwah, NJ: Lawrence Erlbaum Associates.

Schneiderman, J. U., Mennen, F. E., Negriff, S., \& Trickett, P. K. (2012). Overweight and obesity among maltreated young adolescents. Child abuse \& neglect, 36(4), 370-378.

Schuette v. BAMN. (April 22, 2014). No. 12-682. Supreme Court of the United States.

Stillwell, R., \& Sable, J. (2013). Public school graduates and dropouts form the common core of data: School year 2009-10. Washington DC: U.S. Department of Education and The Institute of Education Sciences. Retrieved from http://nces.ed.gov/pubs2013/2013309rev.pdf.

Tanner-Smith, E. E., Wilson, S. J., \& Lipsey, M. W. (2013). The comparative effectiveness of outpatient treatment for adolescent substance abuse: A meta-analysis. Journal of substance abuse treatment, 44(2), $145-158$.

Tate, W. F. (1997). Critical race theory and education: History, theory, and implications. Review of research in education, 22, 195-247.

Tatum, B. D. (1997). "Why are all the black kids sitting together in the cafeteria?” And other conversations about race. New York, NY: Basic Books.

The Movement for Black Lives (2016). Platform. [Web page]. Retrieved from https://policy.m4bl.org/platform.

Thomas, E. E. (2016, November). Stories still matter: Rethinking the role of diverse children's literature today. Language Arts, 94(2).

Urrieta, L. (2006). Community identity discourse and the heritage academy: Colorblind educational policy and white supremacy. International Journal of Qualitative Studies in Education, 19(4), 455-476. doi:10.1080/09518390600773197.

U.S. Department of Education Office for Civil Rights. (2016). 2013-2014 civil rights data collection: A first look. Retrieved from http://www2.ed.gov/about/offices/list/ocr/docs/2013-14-first-look.pdf.

Waller, M. W., Iritani, B. J., Christ, S. L., Clark, H. K., Moracco, K. E., Halpern, C. T., \& Flewelling, R. L. (2012). Relationships among alcohol outlet density, alcohol use, and intimate partner violence victimization among young women in the United States. Journal of interpersonal violence, 27(10), 2062-2086.

Wilder, J., \& Cain, C. (2011). Teaching and learning color consciousness in Black families: Exploring family processes and women's experiences with colorism. Journal of Family Issues, 32(5), 5777-604.

Wildsmith, E., Manlove, J., Jekielek, S., Moore, K. A., \& Mincieli, L. (2012). Teenage childbearing among youth born to teenage mothers. Youth \& Society, 44(2), 258-283.

Wing, A. K. (Ed.). (2003). Critical race feminism: A reader. New York: NYU Press.

Winograd, K. (2011). Sports biographies of African American football players: The racism of colorblindness in children's literature. Race Ethnicity and Education, 14(3), 331-349. Doi:10.1080/13613324.2010.519983.

Wishon, P. M. (2004). Brown v. Board of Education at 50: Reflections on Plessy, Brown, and our professional conscience. Young Children (May), 77-79.

Wood, E. (2003). The power of pupil perspectives in evidence-based practice: The case of gender and underachievement. Research Papers in Education, 18(4), 365-383. doi:10.1080/026715203200017686.

\section{解}

